\title{
Clea Gerber, La genealogía en cuestion: cuerpos, textos y reproducción en el 'Quijote' de Cervantes, Alcalá de Henares, Universidad de Alcalá, Instituto Universitario de Investigación Miguel de Cervantes, 2018, 316 pp.
}

\author{
María Elena Fonsalido \\ Universidad Nacional de General Sarmiento, \\ Argentina
}

Cita sugerida: Fonsalido, M. E. (2020). [Revisión del libro

La genealogía en cuestión: cuerpos, textos y reproducción en

el 'Quijote' de Cervantes por C. Gerber]. Olivar, 20(32),

e087. https://doi.org/10.24215/18524478e087

En abril de 1988 se firmó en Alcalá de Henares, patria chica de Miguel de Cervantes, el acta fundacional de la Asociación de Cervantistas. Fue creada a instancias del abogado y bibliógrafo mallorquín José María Casasayas. En 2009, a cinco años de su muerte, el Ayuntamiento de Argamasilla de Alba (región de CastillaLa Mancha), junto con la Asociación fundada por él, la Universidad de Castilla-La Mancha y la Diputación de Ciudad Real, creó el Premio de Investigación Cervantista que lleva su nombre.

El libro que nos ocupa, La genealogía en cuestión: cuerpos, textos y reproducción en el 'Quijote' de Cervantes, de la investigadora argentina Clea Gerber, ganó la edición 2017 del premio. Se trata de la primera vez que se otorga a un investigador no español. El libro tiene su origen en la tesis doctoral de Gerber, que fue dirigida por Juan Diego Vila y Ruth Fine.

Difícil empresa escribir en el tercer milenio sobre Cervantes. Sobre todo, después de la larga serie de homenajes que, en forma de congresos, libros y artículos se produjeron en 2005 y en 2015, al cumplirse los dos centenarios de las primeras ediciones del Quijote. A pesar de esto, el libro de Gerber asume el desafío. A la erudición exigida por el género, la autora suma un elemento que constituye su novedad: el punto de vista desde el cual se elige leer, lo que permite resignificar lecturas anteriores al tiempo que aporta la nueva. 
El punto de partida elegido por Clea Gerber consiste en asociar en el Quijote las imágenes relativas a la gestación y la reproducción biológica con la creación literaria. Siguiendo este hilo conductor, la autora construye una "familia textual", conformada por los tres Quijotes: los dos “legítimos" y el "espurio", es decir, los textos cervantinos de 1605 y de 1615 y el Quijote apócrifo de 1614.

El libro presenta una estructura coherente con el punto de vista elegido para el estudio: se divide en seis apartados: cinco capítulos más conclusiones. El primer capítulo, que funciona a modo de introducción, especifica el enfoque y las hipótesis de trabajo. En el marco de la consideración del Quijote como punto final de los libros de caballerías y como origen a la novela moderna, Gerber propone, y aquí reside parte de su originalidad, la deconstrucción de la tradicional paridad fecundidad / creación artística, para postular en Cervantes una "poética de lo estéril" (2018:20, destacado en el original). A partir de esta aparente contradicción, el trabajo demostrará cómo "una poética que designa al artificio como aquello que, surgido de una gestación paradójica o desviada del orden natural, resulta capaz, por lo mismo, de producir un ejemplar verdaderamente original" (20, destacado en el original). Para poder lograrlo, se examinan en este capítulo tres conceptos que, según Gerber, cumplían un rol central en el imaginario social del siglo XVII: la paternidad, la genealogía y la reproducción.

El segundo capítulo constituye uno de los puntos centrales y más logrados del libro: el detallado análisis del prólogo de 1605, considerado por el texto como la exposición del programa cervantino. Gerber trabaja sobre el concepto mismo de prólogo. Considera la duda respecto de su carácter ficcional o no ficcional; su propósito de señalar las líneas directrices de la novela; su condición de espacio privilegiado de la función autor y de la voz autorizada que esto implica, deconstruido por Cervantes en el diálogo entre el autor dubitativo y su pragmático amigo. Las relaciones entre autor, libro y personaje se enlazan en este análisis del prólogo cervantino, análisis que propone como puntos de partida de la novela inaugural de occidente el parto fallido, la paternidad desviada, el hijo loco y marginal.

El tercer capítulo se centra en el Quijote de 1605. Allí Gerber demuestra cómo el "plan” cervantino propuesto en el Prólogo encuentra su cauce. Se analizan, entonces, las relaciones entre parto, nacimiento, muerte. Los efectos producidos en los cuerpos devienen en textos, ya que, como explica la autora "en 1605 [...] se trata de poner en escena los mecanismos de producción de un espécimen original” (91, destacado en el original). Esta producción será considerada siempre fruto de un desvío del orden natural. Desde este punto de vista, el "donoso escrutinio", el hallazgo del manuscrito escrito en árabe en Toledo, los relatos orales, los epitafios finales, los “autores” internos del texto (Cardenio, Grisótomo, Ginés de Pasamonte, el canónigo) entre otros episodios, momentos o personajes de la novela, adquieren una dimensión diferente de la habitual. En el mismo sentido, el estudio de la relación entre cuerpos humanos y cuerpos textuales resignifica los componentes semíticos de la novela. En la línea de investigadoras como Ruth Fine o Luce López-Baralt, Gerber considera a la novela cervantina como modelo del cruce entre las herencias judía, árabe y cristiana, a lo que debe sumar la problemática de los conversos. Esta exposición de culturas y de voces en pugna difumina el concepto de autor (auctoritas) y, por ende, el de "paternidad" textual.

En el cuarto capítulo, la investigadora considera el Quijote de Avellaneda. Lejos del denuesto que resulta casi un tópico académico al analizar este texto, Gerber se corre de la postura de la enemistad personal entre los dos autores, para proponer "una disputa estético-ideológica entre escritores pertenecientes a cenáculos divergentes" (158). Sin apartarse de la óptica elegida, postula que "su trabajo [el de Avellaneda] sobre el universo simbólico de la paternidad y la herencia difiere por completo del cervantino" (149). Se refiere la autora a que la novela de 1614 pretende borrar el desvío que realiza Cervantes en el incipiente género y volver a la postura moralizante y ejemplificadora. De este modo, Avellaneda se aparta de los procesos de transformación que constituyen el eje quijotesco de 1605, para "normalizar" personajes, situaciones e ideologías.

El último capítulo se centra, obviamente, en el Quijote de 1615. Si, como ya se dijo, el primer Quijote ponía su centro en la producción de los textos y los personajes, capaz de transformar la tradición precedente, según 
Gerber, el segundo Quijote "profundizará esa reflexión a partir de una marcada preocupación por los modos espurios de reproducción de los textos" (199, destacado en el original). Es por esta razón que el capítulo presta especial atención a dos "linajes" relacionadas con esta reproducción: las familias del libro (los Panza, Diego de Miranda y su hijo, la dueña Rodríguez y su hija, el morisco Ricote y la suya -lo que nuevamente permite poner en foco la cuestión de los conversos en la novela y comparar los modos en que esta situación es tratada en 1605 y en 1615-) y las continuaciones literarias. Por otro lado, si en el capítulo dedicado al Quijote de 1605 se prestó especial atención a la tríada nacimiento/vida/muerte, en este último Gerber se centra en el concepto de resurrección. A través de su tratamiento (los casos de Basilio y Altisidora), al que liga con reediciones y reapropiaciones del ámbito literario, la autora propone un nuevo modo de leer la manera en que Cervantes incorpora al texto la disputa con la continuación espuria.

Finalmente, tres notas respecto del libro en tanto objeto: en primer lugar, la nota de practicidad la da el hecho de que cada capítulo culmina con una "Recapitulación" de dos o tres páginas, lo que permite al estudioso revisar y asentar los conceptos leídos. En segundo lugar, la nota de especificidad la proporciona la división de la bibliografía, en la cual un apartado reúne los textos referidos al Quijote de Avellaneda. En tercer lugar, y no por ello menos importante, la nota de belleza la proporciona una "donosa” tapa, con una imagen realizada por Albert de la quema de la biblioteca de don Quijote, correspondiente a la edición francesa de la novela, a cargo de Louis Janet (siglo XIX).

El desafío que se menciona al principio, producir una nueva lectura sobre la novela más analizada en la historia de la literatura, se asume con agudeza. La autora consigue realmente leer el Quijote desde otro lugar, echar nuevas luces sobre el texto, abrir dimensiones inéditas. El trabajo de Clea Gerber, al tiempo que tematiza las genealogías cervantinas, se inscribe, a su vez, en lo más destacado de la genealogía de la crítica cervantina argentina. El texto continúa lo mejor de la tradición que marcaron Celina Sabor de Cortazar e Isaías Lerner y le augura al cervantismo argentino larga y próspera vida. 